\title{
STUDENTS VALUATION OF THE USE OF COMPUTERS IN EDUCATION
}

\author{
B. GERARD DoORnekamp \\ University of Twente, Centre for Applied Research in Education (OCTO), P.O. Box 217, \\ 7500 AE Enschede, The Netherlands
}

\begin{abstract}
Two schools for general secondary education in Enschede, The Netherlands took part in a 4-yr Technology-enriched Schools project. One of the research questions in this project was the valuation by the students of the use of computers in education. It was hypothesized that this valuation would be influenced by factors which deal with the perception of the student, the use of computers in teachinglearning situations, the circumstances in which the computers are used, and background information on the students. It was also hypothesized that the frequent use of computers in education could make the students less enthusiastic about computers.

The research questions were investigated by means of two instruments with identical content: a paper-and-pencil questionnaire and a computerized questionnaire. The questionnaire was administered to 816 students. About $20 \%$ of the students had had considerable experience with computers outside of school-hours.

Results show that some students had used the computer at school very frequently. There was no evidence found in this study that students with much computer experience at school valued the use of computers in education differently than did students who had little experience. The intensity with which the computers were used by the teachers of the technology-enriched schools did not have a restraining influence on the enthusiasm and the motivation of the students.
\end{abstract}

\section{INTKODUCIION}

In 1987 the Dutch Ministry of Education and Science started the 'Technology-enriched Schools' project (TES-project). The aim of the TES-project was to investigate various ways of realizing computer integration in technology-enriched secondary schools[1].

Two technology-enriched schools for general secondary education in Enschede took part in this project. At that time, one school had about 850 students and 65 teachers, the other school about 1400 students and 90 teachers.

In 1991 the schools were equipped with 45 computers each, spread over two computer rooms and some stand-alone units used for demonstration in the teachers' own classrooms. The schools each received funding for $25 \mathrm{~h}$ a week of released time for teachers participating in the project and $10 \mathrm{~h}$ a week of released time for two computer coordinators. Furthermore, the participating schools received a budget for the purchase of courseware and for the organization of in-service training.

A team of researchers from the Faculty of Educational Science and Technology and the Centre for Applied Research in Education of the University of Twente conducted a program of research on the implementation process of information technology in these schools[1].

As some idea of the extent of the project, the following descriptive data may be helpful. The computers were used for organizational and management purposes and for educational purposes. In Autumn $199061.5 \%$ of the teachers $(n=143)$ had used the computer at school. From this group of teachers $61.3 \%$ had used the computer for educational purposes. The use of computers in education was not restricted to certain departments. All departments were allowed to buy courseware and to use the computers in the computer room or the stand-alone units. The computer rooms were given preference over the stand-alone units. Over $80 \%$ of the teachers who used the computer for educational purposes did so in one of the computer rooms, while $7 \%$ of the teachers had used a stand-alone unit (10\% of the teachers used both possibilities).

It also appeared that some members of a department used the computers in the computer education very frequently, while other members used these computers only a few times or did not use the computer at all.

The members of the Information Technology Department used the computer room very frequently. When this Department was left out of consideration the other subjects areas varied 
greatly in their use of the computer rooms. The Departments of Dutch, French, mathematics and history were frequent users, while (among others) German, English, chemistry and economics were not [2].

This paper deals with COMPRO (Computers in Pilot schools), one of the research projects of the overall TES-project. Since the start of this project the research questions have focused mainly on the teacher, e.g. the concerns of teachers, the selection of courseware, the integration of courseware in the curricula, but in the last stage of the project attention was also paid to the students $[3,4]$.

\section{SIUDENIS AND COMPUIERS}

The students are an important target group of the use of computers in education. Their opinions on computers and courseware are extremely relevant, because the students are the consumers of hardware and courseware. A side factor is the rather unique situation at the technology-enriched schools. During several years the use of the computer rooms was closely monitored. Information was thus available on the past history of these students with regard to their use of computers at school[5]. In this computer-enriched environment, the students came into regular touch with computers. 'This depended however, on the teachers who taught the students. Since the start of the project most of the students had been introduced to computers in the computer room.

From several studies regarding motivation and computers it can be concluded that the use of computers in secondary education increases, at least at the start, the motivation of the students $[6,7]$. The students have a better perception of learning compared with the traditional way of teaching [6], though effective achievement does not increase [8]. As far as student-controlled or program-controlled instruction is concerned, the former is generally preferred by the students because it gives them the perception of personal control. According to Kinzie and Sullivan [6], effects on achievement can be expected in the long-term because of the effect of student control on motivation.

For students the experience with computers can also be an unpleasant one. Marcoulides[9] reports that many students respond enthusiastically and master the skills for effective application of the computers, but there are also students who exhibit anxiety. This negative emotional reaction towards computers influence the degree to which computers can be effectively utilized [9].

Several studies [10-13] investigated possible differences between girls and the boys regarding the use of computers. Ransley [10] used a 17-item instrument to assess the attitude of 12-yr-old children. She identified five aspects and found that the girls had significantly more positive attitudes for the functioning of the computer than the boys, but the girls are more negative about the difficulty when working with computers. For the other aspects, involvement with computers, attractiveness of using computers, and novelty of working with computers, there appeared to be no difference between girls and boys[10]. Chen [11] found gender differences in programming and voluntary activities. Male high school students were more likely to have taken a programming class or to report the presence of a home computer and also used their home computers more frequently than did females. More male students participated in computer clubs or used a friend's computer. Chen also reported the males would hold more positive attitudes towards computers. They were more interested in, had more self-confidence with, and were less intimidated by computers. Females and males with similar amounts of experience had equivalent levels of interest in computers and their interest in computers increased with levels of experience[11]. Asskar et al.[12] investigated the attitudes of another group: girls and boys at elementary schools (fifth graders). In their study they did not find significant differences between the girls and the boys. Asskar et al. regard this as an indication that the attitudes of those pupils are not affected by some social and cultural factors which may cause a difference. The girls and the boys shared also similar levels of computer experience.

From the beginning of the TES-project, the teachers of the two technology-enriched schools reported at meetings that the students who had lessons in the computer room appeared to be very enthusiastic. They seemed to like those lessons more than their ordinary lessons. Subject matter the students were not interested in during ordinary lessons was enjoyed in the computer room. But after many lessons in the computer room the students might not be so enthusiastic as before. 
The novelty effect might disappear. Or will the students still be enthusiastic about computers? It is generally well-known that when a certain teaching method is used repeatedly, the students will become bored [14] and when the courseware is too difficult, they can lose their motivation [15]. Thus to keep students motivated, variation in teaching methods is needed. It can be predicted that instruction by means of the computer, as a teaching method, can also become boring when the teachers use the computer too many times.

\section{THE RESEARCH QUESTION}

For this part of the study two general research questions were formulated: "How do the students experience the use of the computer as a tool in lessons? Is there enhanced motivation, that persists in the long-term?" After discussion within the COMPRO project the first research question was elaborated into three more specific research questions [3,4]:

(1) How do the students of technology-enriched schools in general secondary education value the use of computers in education?

(2) Which factors, in particular the gender of the students, are related to this valuation by the students?

(3) How do students who have had many lessons during successive years in the computer room value the use of computers in education?

The following aspects were predicted to be of importance in the second research question:

- the perception of the student;

- the use of computers in teaching-learning situations;

- the factors that are related to this use of computers;

- the background factors of the students.

The factors that were related to the use of computers could be divided into two groups:

(1) Factors which dealt with the use of the computer itself. The factors were characteristics by which courseware packages could be distinguished from each other. The students were questioned how they valued these characteristics in a particular courseware package. Examples of these characteristics were: interactivity, individualization, and practice[16].

(2) Factors which could be related to the circumstances in which the computers were used. During a lesson the students worked alone or in pairs while the teacher helped them, on their request. Examples of these circumstantial factors were: alone or in pairs, courseware, guidance by the teacher, and availability of equipment [17].

A number of background variables played a part in the interpretation of the differences in the valuation of certain groups of students. The factors which were identified for this study were: school, grade, gender, age, achievement level, computer experience at school in successive years, and experience with computers outside of school-hours [17].

\section{METHOD}

\section{Background variables and courseware evaluation}

The research questions were investigated by means of a questionnaire[18]. The questionnaire consisted of two parts. The questions of the first part referred to (a) background information on the student (school, grade, gender, and age), (b) the use of computers outside of school-hours, (c) computer use alone or in pairs in the computer room, and (d) a general valuation of the use of computers in education. In the second part of the questionnaire the students had to evaluate two out of five courseware packages. For each school grade the five best-used packages were selected. Students only needed to evaluate two packages they had used in the current school year. 
From a pre-test we learned that when the students had three or more packages, they lost concentration. Therefore the number was limited to two[17].

The computer coordinators were asked to indicate the achievement level of the students who participated in this study. They also gave information on the school career of those students. This information was needed to establish the degree of computer experience gained at school in successive years.

\section{Instruments}

For the study two versions of the questionnaire were developed: one using paper-and-pencil and the other a computer. Both contained the same questions; only the ways the questionnaires were administered differed. It was not the aim of this article to compare the instruments, that has been published elsewhere [19].

Usually a paper-and-pencil questionnaire is used to collect data when a large group of respondents is involved $[20,21]$, but very frequently the respondents do not fill it out correctly: questions are skipped or questions that do not apply are answered. On completion, the data have to be entered into the computer before they can be analyzed[22], which is time-consuming.

By using a computer the respondents can be guided through the questionnaire. They only need to answer those questions that apply to their situation. The remaining questions are not shown. The computer also makes it possible to record the answers of the respondents. After administration, the data are ready to be analyzed.

First, the paper-and-pencil questionnaire was developed. The content was based on the factors that are related to computers and the background variables (see previous section). In spring of 1991 the prototype version of the questionnaire was administered to a small group of students $(n=31)$ in both schools.

After this administration, the questionnaire was evaluated and adjusted, and the development of the computerized version of the questionnaire started. For this purpose the authoring system TAIGA (Twente Advanced Interactive Graphic Authoring System) was used [23]. The authoring system consists of several modules. One of the modules makes it possible that the recorded answers of the students are written to a data file which can be read by SPSS (Statistical Package for the Social Sciences). This saves considerable time. The prototype version of the computerized questionnaire was administered to 20 students of both schools in December 1991, using an AT-computer with a color screen. A short introduction preceded the actual administration of the questionnaire. The students were pleased with this method though it took more time than with paper and pencil because of the slow speed of the computer.

\section{Procedure}

From each grade (Grade 7 up to and including Grade 11), three classes (lower, medium and upper level) were selected. From Grade 12 only two classes were selected because of the relatively small number of students in this grade. Each selected class (approx. 25 students) was split up into two equal groups. Girls and boys were spread equally over both groups. One group, about half of the students, filled out the paper-and-pencil questionnaire and the other the computerized questionnaire. It was the intention that per technology-enriched school approx. 425 students would participate in this study.

The questionnaires were administered at the beginning of 1992 .

\section{Subjects}

In total 816 students participated in the study. The two schools took part almost equally (425 students of school A and 391 students of school B). The number of students per grade varied with school. The average number of students per class was 24 (school $\mathrm{A}=25$, and school $\mathrm{B}=23$ ).

The questionnaire (both versions) was filled out by 440 girls $(53.9 \%)$ and 375 boys $(46.0 \%)$. One student did not answer the gender question.

The age range of the students was from 12 (Grade 7) to 21 years (Grade 12). It was not usual that a student of Grade 12 is this old. Twclve students did not indicate their data of birth correctly. The sample was divided equally over the two questionnaires, the two technology-enriched schools, and the two sexes. 


\section{Additional information on the sample}

Additional information on the students in the sample was obtained from the computer coordinators of the technology-enriched schools for computer experience at school in successive years, and achievement level).

Computer experience at school in successive years. The teachers had been using the computers in their lessons, mostly in the computer rooms since the beginning of the project. During the last 3 years the usage of the computer rooms had been recorded, to $\log$ how many times a class visited a computer room, etc.

The computer coordinators of the technology-enriched schools provided information on school careers during the last 3 years of the TES-project. With this information it was possible to determine the computer experience at school for each student. A complicating factor was the educational organization of the upper level of these schools. Students formed part of a class, but also formed part of a cluster depending on the subject areas the students had chosen for their final examinations. The class codes as well as the cluster codes were recorded, but it was not always clear to which cluster a student belonged. Because of this, some information was lost. The amount of computer experience at school could thus be higher for some students than indicated by the data.

The sample was divided into three categories: low, medium, and high, scored 1, 2, and 3, respectively. Nearly $13 \%$ of the students $(n=816)$ had acquired much computer experience at school over a period of 3 years. Nearly half of the students had average experience and $40 \%$ had little in-school experience with computers. There was no difference $(t=0.23 ; \alpha \leqslant 0.05)$ between the boys (1.74) and the girls (1.73).

Achievement level of the students. The computer coordinators were also asked to indicate the achievement level for each student, in three categories scored 1, 2, and 3, respectively: weak (poor marks at school, will not pass), average (good and bad marks, will perhaps fail), and good (good marks, will be moved up). The coordinators were able to consult the teacher counsellors of the students.

Technology-enriched schools are combined schools, with several types of secondary education present. Consequently achievement levels from different types of secondary education were not comparable and, the coordinators had to evaluate the students of each type of secondary education independently. Fourteen students had not written their names on the questionnaire and were not included.

The factor achievement level indicated that $22.3 \%$ of the students $(n=802)$ were weak, $46.1 \%$ were average, and $31.6 \%$ were good.

The average achievement level of the girls (mean 2.11, SD 0.75) was the same as the boys (mean 2.07 , SD 0.70), $(t=0.74, \alpha \leqslant 0.05)$.

\section{RESULTS OF PART I}

The use of computers outside of school-hours

Many students had acquired experience with computers outside school hours including free periods at school. Nearly two-thirds of the 816 students had used a computer outside school hours, especially Grades 7, 8 and 9. Most of them had used a computer at home, but sometimes also a friend's or a relative's (Table 1). Students were allowed to tick two or more alternatives.

The frequency with which the computer was used by students varied from about once in 6 months to a few times per week (Table 2).

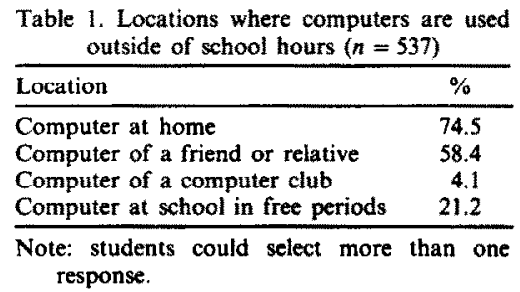

Table 2. Frequency of computer use outside school hours $(n=537)$

\begin{tabular}{lc}
\hline Frequency & $\%$ \\
\hline About once in 6 months & 14.2 \\
About once per month & 23.1 \\
About once per week & 24.8 \\
A few times per week & 37.2 \\
Not answered & 0.7 \\
\hline
\end{tabular}




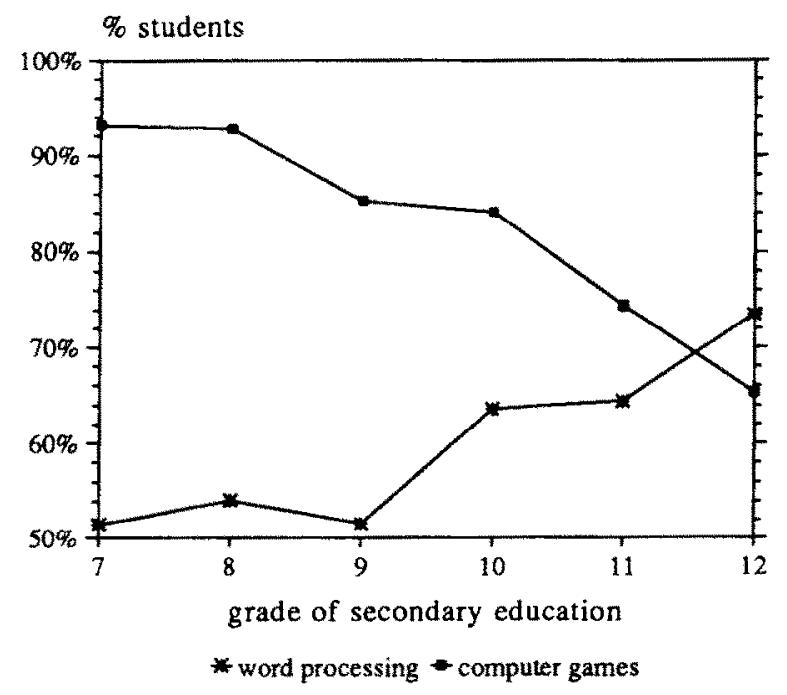

Fig. 1. The use of the computer outside school for word processing and computer games.

About $40 \%$ of the students used the computer very frequently. Students in Grades 10,11 and 12 used the computer less frequently than the other students. Boys (3.20) used the computer more frequently than the girls $(2.55)(t=7.30, \alpha \leqslant 0.05)$.

The computer can be used for several purposes, so students were allowed to tick more than one alternative. Nearly $60 \%$ of the students $(n=537)$ used the computer for word processing, nearly $85 \%$ for computer games, and about $20 \%$ for learning programs.

Computer games were very popular among the students. There was a difference related to age that was noticeable with regard to use of computers outside of school: students in lower grades used the computer mostly for computer games and less for word processing, while students of higher grades give preference to word processing over computer games (Fig. 1),

The results of the questions related to the use of a computer by the students outside of school-hours, e.g. at home, were used to create a variable called experience with computers outside of school-hours. The sample was divided into three categories: low, medium, and high. Although many students had experience with computers outside school-hours, only $17 \%(n=816)$ had much experience, $31 \%$ had medium experience, and $52 \%$ had little experience.

Figure 2 shows that there was no relationship between the factors computer experience outside of school-hours and computer experience at school in successive years (discussed in the previous section) in these samples.

\section{Alone or in pairs in the computer room}

The students work alone or in pairs with the computer while at school. The grouping depends on the size of the class, the number of computers that are available, and the goal of the lesson or courseware. A little less than the half of the students $(42.3 \%, n=815)$ preferred to work alone, $27.7 \%$ of the students preferred to work in pairs, and $29.9 \%$ of the students answered that it did not matter to them. Students from Grade 7 more often preferred to work alone over working in pairs than did students from the other grades. The boys did not like to work in pairs so much. Of those who preferred to work in pairs $(n=226)$, only $37 \%$ were boys and $63 \%$ were girls. Most of the students who had a preference for working in pairs at school had low computer experience outside of school-hours. About $63 \%(n=226)$ had low computer experience outside of school-hours.

When the student work in pairs and may choose a partner, nearly $80 \%$ of the students $(n=815)$ chose a class-mate with whom they work together frequently. About $3 \%$ of them chose a class-mate who is good in computers, $2 \%$ chose a class-mate who is good at the subject area and $15 \%$ had no preference at all. Knowledge about computers or the subject area was not important for the student. They preferred a class-mate with whom they had a good relationship. In contrast, students of Grades 11 and 12 chose less often a class-mate with whom they work together frequently, but 
computer experience at school

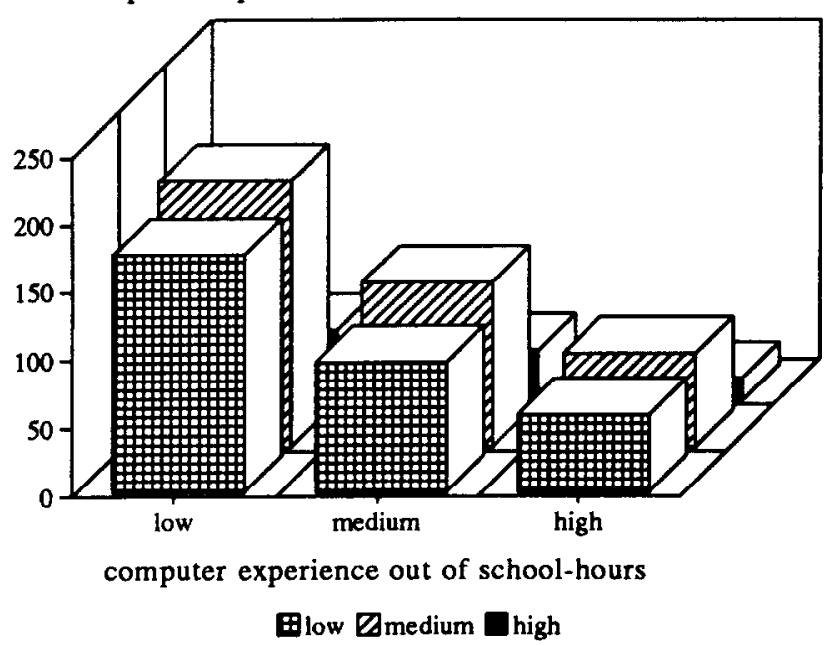

Fig. 2. The relationship between computer experience outside of the school-hours and computer experience at school in successive years.

chose more often 'does not matter'. When choosing a partner, the gender of that partner can also play an important role. For the majority of the students $(70.3 \%, n=814)$ it did not matter about the gender of the partner. Boys chose more often for a boy to work with $(9.2 \%)$ than girls chose a girl to work with $(7.2 \%)$.

\section{Statements regarding the use of computers in education}

A number of statements (19) regarding various aspects of the use of computers in education were put before the students. They had to indicate whether they agreed or not with these statements. The results (see also[5]) showed that about $60 \%$ of the students did not think they would subsequently choose to study computers more or to aim to work in a profession in which computers are used. In contrast, the students (about $75 \%$ ) did want to use the computer more often in the lessons or in free periods. The students $(72 \%)$ liked the programs that were used at school. About $60 \%$ liked to work with computer programs with which they have to do many exercises, and over $80 \%$ thought that they learn well from those programs.

Whether the students like a certain computer program or not depends on the subject of that program $(90 \%)$, but does not depend on the teacher $(76 \%)$.

A word processor is a useful tool according to $90 \%$ of the students. Nearly $65 \%$ think it is important to learn how to develop a computer program.

Nearly all the students like it that there is a teacher able to help them when they are in trouble with the computer or have questions about the subject matter. However, three-quarters of the students think that it is not difficult to operate a computer.

\section{Factor analysis}

The answers of the students were analyzed by means of factor analysis which resulted in seven scales. Each scale was comprised of three statements, except Scales 3 and 4, on which were two statements. Table 3 gives the results of the analysis.

For each student a scale score was calculated for each scale. A frequency distribution of the results is given in Table 4.

The seven scales were analyzed in order to determine which background variables (school, grade, gender, age, achievement level, computer experience at school in successive years, and computer experience outside of school-hours) were related to the scale scores of the students. This was investigated by means of an analysis of variance for each scale separately. Because of the number of independent variables, only the main effects of these variables were calculated (interaction effects were omitted). The results of the separate analyses are joined together and are shown in Table 5. 
Table 3. Results of the factor analysis: description, eigenvalues, and factor loadings of the seven factors

\begin{tabular}{|c|c|c|c|c|c|c|c|}
\hline Factor & 1 & 2 & 3 & 4 & 5 & 6 & 7 \\
\hline Description & Education & Future & Practice & Assistance & Lessons & Courseware & Experience \\
\hline Eigenvalue & 3.22 & 1.97 & 1.37 & 1.25 & 1.78 & 1.08 & 1.04 \\
\hline \multicolumn{8}{|l|}{ Statements (shortened) } \\
\hline Subsequent study about computers & & 0.82 & & & & & \\
\hline Prefer a familiar progam rather than a new one & -0.12 & -0.24 & & & 0.29 & 0.18 & 0.65 \\
\hline Programs are boring me after several times & & & & & & 0.36 & -0.69 \\
\hline Use computers in education more often & $\underline{0.86}$ & 0.12 & & & -0.15 & & \\
\hline Like programs with exercises & $\overline{0.16}$ & & $\underline{0.75}$ & & & & \\
\hline Occupation in which computers are used & 0.15 & $\underline{0.77}$ & & -0.10 & -0.13 & & \\
\hline Do not like old programs so much any ...ore & 0.10 & & -0.43 & & -0.14 & $\underline{0.51}$ & -0.10 \\
\hline Learn well with exercises in programs & 0.17 & & 0.71 & 0.17 & & & \\
\hline A word processor is a useful tool & 0.11 & 0.20 & $\overline{0.16}$ & & -0.27 & 0.20 & 0.46 \\
\hline Subject determines like program or not & -0.10 & & & 0.21 & & 0.66 & \\
\hline Learn to make programs at school & 0.24 & 0.50 & 0.26 & & 0.10 & & -0.11 \\
\hline Like to look at the screen of class-mates & 0.10 & & & & 0.62 & 0.30 & \\
\hline Like to use programs at school & 0.77 & & 0.23 & & & -0.10 & \\
\hline Assistance with the operation of the computer & & & 0.14 & $\underline{0.80}$ & 0.14 & & \\
\hline Teacher determines like program or not & & -0.10 & 0.18 & $-\overline{0.33}$ & 0.24 & 0.49 & -0.13 \\
\hline Pleasant when teacher explains subject matter & & & 0.10 & 0.80 & & 0.11 & \\
\hline It is difficult to operate computers & -0.31 & -0.10 & 0.13 & & 0.61 & & 0.11 \\
\hline Like to use a mouse with the computer & & & 0.11 & -0.14 & -0.57 & 0.22 & 0.14 \\
\hline Use compter at school more often & $\underline{0.88}$ & 0.17 & & & -0.10 & & \\
\hline
\end{tabular}

Note: factor loadings with values between -0.10 and 0.10 are omitted.

The variable gender is significantly related to four out of seven of the factors, while the variables achievement level and age had no significant relation to these factors. The factor Future was related to four background variables. Girls have a lower mean scale score (1.14) on this factor than the boys (1.47). Students who have much computer experience outside school hours or much computer experiment at school have a higher mean scale score (1.56) on this factor than those who have less experience (1.25). Students of the higher grades (Grades 10,11 and 12) have a lower mean score (1.15) on this factor than students of the Grades 7, 8 and 9 (1.42).

\section{RESULTS OF PART II}

In the second part of the questionnaire the students answered questions regarding the courseware they had used in the current school year. Fach student evaluated at most two packages. A number of packages (29) were evaluated by the students. The number of students per package was not equal: this number varied from 230 students to 1 student per package. Those packages that were evaluated by less than 50 students were ignored. This left 10 courseware packages. For each package there were two main questions: 'do you like the courseware?' and 'do you think you have learned well with the courseware?' The results of these questions for those 10 packages are shown in Table 6. In this table the percentages of students that answered 'yes' are mentioned.

Table 6 shows that the majority of the students liked the courseware packages they selected, except $G$ and $J$. Also a majority of the students thought that they had learned well with the courseware, except package $\mathbf{J}$. What the student may have learned with the courseware is not investigated in this study.

In five case, the packages B, C, E, G, and I, the percentage of students that liked the courseware is smaller than the percentage of students that thought that they have learned well with the courseware. This implies that perceiving one has learned well with courseware does not imply that the student will also like the courseware.

Table 4. Frequency distribution per scale $(n=816)$

\begin{tabular}{lccccccc}
\hline & \multicolumn{7}{c}{ Factors and descriptions } \\
Scale- & 1 & 2 & 3 & $\mathbf{4}$ & 5 & 6 & 7 \\
scores & Education & Future & Practice & Assistance & Lessons & Courseware & Experience \\
\hline 0 & 128 & 211 & 119 & 27 & 122 & 53 & 7 \\
1 & 66 & 297 & 224 & 56 & 363 & 330 & 217 \\
2 & 108 & 166 & 473 & 733 & 278 & 338 & 432 \\
3 & 514 & 142 & - & - & 53 & 95 & 160 \\
\hline
\end{tabular}


Table 5. Results of the analyses of variance for each of the seven factors: $F$-values of significant main effects $(\alpha \leqslant 0.05)$

\begin{tabular}{|c|c|c|c|c|c|c|c|}
\hline \multirow[b]{2}{*}{$\begin{array}{l}\text { Background } \\
\text { variable }\end{array}$} & \multicolumn{6}{|c|}{ Factors and descriptions } & \multirow[b]{2}{*}{$\begin{array}{c}7 \\
\text { Experience }\end{array}$} \\
\hline & $\begin{array}{c}1 \\
\text { Education }\end{array}$ & $\begin{array}{c}2 \\
\text { Future }\end{array}$ & $\begin{array}{c}3 \\
\text { Practice }\end{array}$ & $\begin{array}{c}4 \\
\text { Assistance }\end{array}$ & $\begin{array}{c}5 \\
\text { Lessons }\end{array}$ & $\begin{array}{c}6 \\
\text { Courseware }\end{array}$ & \\
\hline Gender & - & 14.67 & 26.67 & 25.88 & - & 5.26 & - \\
\hline Grade & 9.87 & 2.43 & - & - & 2.82 & - & - \\
\hline Computer experience outside school hours & - & 9.20 & - & 10.94 & - & - & 5.82 \\
\hline Computer experience at school & - & 4.08 & - & - & - & - & - \\
\hline Achievement level & - & - & - & - & - & - & - \\
\hline Age & - & - & 一 & - & - & - & - \\
\hline Technology-enriched school & - & - & 6.01 & - & 12.00 & 6.95 & - \\
\hline
\end{tabular}

Note: non-significant $F$-values omitted.

Table 7 shows that girls and boys did not have the same opinion regarding the two main questions.

The girls liked the packages more often than the boys ( 6 out of 10 packages) and thought more often that they had learned well with the package ( 6 out of 10 packages).

The students liked the packages for two reasons:

working with the computer is a pleasant change from ordinary lessons $(69.5 \%)$, and the students like to work with the computer very much $(58.3 \%)$.

For learning well with a package there were three arguments:

there is enough time to read the explanation $(56.9 \%)$,

there are many exercises included in the courseware $(54.5 \%)$, and

the explanation given in the courseware is comprehensible $(51.9 \%)$.

The students did not learn so well with the packages if:

they thought the packages are dull $(32.3 \%)$ or

the students had learned the subject matter before in the lessons $(30.6 \%)$.

The answers to the two main questions per package were analyzed using the same procedure that was used to analyze the factor scores (Results Part I). The number of independent variables was not always the same in each analysis because some packages were only used in one of the technology-enriched schools. There were no significant main effects $(\alpha \leqslant 0.05)$ with the first main question relating to students' experience of the computer. None of the background variables were related to the answers on this question about the 10 packages.

The analyses of the second main question relating to students' enhanced motivation showed that there are only significant main effects $(\alpha \leqslant 0.05)$ with the five packages (A-E inclusive). Table 8 shows the results of the analyses for the five packages.

For each package there were one or two main effects where the background variable was significantly related to one or more of the packages. The mean score of students who had much computer experience outside of school-hours (mean 0.88, SD 0.32) on the second main question regarding package $\mathrm{A}$ was higher than the mean score of students with average or little experience (mean 0.61, SD 0.49).

More girls thought that they had learned well with package B (mean score 0.85 , SD 0.36) than the boys did (mean score 0.69, SD 0.47). Students of Grade 2 and 3 (mean score 0.90, SD 0.30) are more positive than students of Grade 4 and 5 (mean score 0.64 , SD 0.48 ) with the second main

Table 6 . Evaluation of 10 courseware packages by students as percent of affirmative answers

\begin{tabular}{lccc}
\hline $\begin{array}{l}\text { Courseware } \\
\text { letter and name }\end{array}$ & $\begin{array}{c}\text { Number of } \\
\text { students }\end{array}$ & Like it? & $\begin{array}{c}\text { Learn well } \\
\text { with it? }\end{array}$ \\
\hline A WordPerfect 5.0 & 230 & 72.6 & 63.5 \\
B Franse Werkwoorden & 185 & 69.2 & 77.3 \\
C EDUC-Schaal & 80 & 57.5 & 76.3 \\
D EDUC-Bevolkingsgeografie & 69 & 66.7 & 50.7 \\
E De Baas & 67 & 58.2 & 67.2 \\
F Tekstnet & 64 & 81.3 & 78.7 \\
G Breuken & 59 & 39.0 & 67.8 \\
H Eetmeter & 59 & 57.6 & 55.9 \\
I Alpha-Word & 58 & 79.3 & 86.2 \\
J Taalkist & 50 & 26.0 & 26.0 \\
\hline
\end{tabular}




\begin{tabular}{|c|c|c|c|c|}
\hline \multicolumn{2}{|c|}{$\begin{array}{l}\text { Courseware } \\
\text { package }\end{array}$} & \multirow{2}{*}{$\begin{array}{c}\begin{array}{c}\text { Girls } \\
\text { mean }\end{array} \\
0.73\end{array}$} & \multirow{2}{*}{$\begin{array}{c}\begin{array}{c}\text { Boys } \\
\text { mean }\end{array} \\
0.72\end{array}$} & \multirow{2}{*}{$\frac{t}{0.05}$} \\
\hline A & WordPerfect 5.0 & & & \\
\hline & & 0.66 & 0.67 & 0.19 \\
\hline \multirow[t]{2}{*}{ B } & Franse Werkwoorden & 0.73 & 0.64 & 1.40 \\
\hline & & 0.85 & 0.69 & $2.60^{*}$ \\
\hline \multirow[t]{2}{*}{$\mathrm{C}$} & EDUC-Schaal & 0.53 & 0.62 & 0.83 \\
\hline & & 0.84 & 0.73 & 1.13 \\
\hline \multirow[t]{2}{*}{ D } & EDUC-Bevolkingsgeografie & 0.59 & 0.79 & 1.75 \\
\hline & & 0.39 & 0.73 & $2.84^{*}$ \\
\hline \multirow[t]{2}{*}{$\mathbf{E}$} & De Baas & 0.69 & 0.50 & 1.56 \\
\hline & & 0.81 & 0.62 & 1.68 \\
\hline \multirow[t]{2}{*}{$\mathbf{F}$} & Tekstnet & 0.79 & 0.84 & 0.44 \\
\hline & & 0.81 & 0.88 & 0.70 \\
\hline \multirow[t]{2}{*}{ G } & Breuken & 0.46 & 0.29 & 1.28 \\
\hline & & 0.77 & 0.57 & 1.67 \\
\hline \multirow[t]{2}{*}{$\mathbf{H}$} & Eetmeter & 0.63 & 0.50 & 0.97 \\
\hline & & 0.74 & 0.42 & $2.54^{*}$ \\
\hline \multirow[t]{2}{*}{ I } & Alpha-Word & 0.87 & 0.70 & 1.58 \\
\hline & & 0.97 & 0.74 & $2.60^{*}$ \\
\hline \multirow[t]{2}{*}{$\mathrm{J}$} & Taalkist & 0.33 & 0.16 & 1.41 \\
\hline & & 0.30 & 0.22 & 0.57 \\
\hline
\end{tabular}

$* \alpha \leqslant 0.05$.

question. The students of school A have a higher mean score (0.95, SD 0.22) than the students of school B (mean score 0.72, SD 0.45) with respect to package C. Students of 13 years are more positive (mean score 0.87 , SD 0.34 ) than 12-yr-old students about this package (mean score 0.68 , SD 0.48). With package $D$ there is a great difference between boys and girls: the boys have a higher mean score $(0.73, \mathrm{SD} 0.45)$ than the girls (mean score 0.39 , SD 0.49). The students of Grade 6 (mean score 0.37 , SD 0.49) are more negative than the students of Grade 5 (mean score 0.63, SD 0.49). More girls (mean score 0.81, SD 0.40) than boys (mean score 0.62, SD 0.49) thought that they had learned well with package $\mathrm{E}$.

The background variables achievement level and computer experience at school are not related to the valuation of the students.

\section{CONCLUSIONS}

In general, the students of the two technology-enriched schools liked the use of computers in education. It was a pleasant change from ordinary lessons. The students like most of the courseware.

There is a difference between the girls and the boys regarding the use of computers outside school-hours and at school, and the girls value the use of computers differently from the boys.

Some students used the computer at school very frequently. There is no evidence in this study that such students value the use computers in education different from students who have little experience with computers at school. The intensity with which the computers are used by the teachers of the two technology-enriched schools had no influence on the enthusiasm and the motivation of the students. The conclusions can be regarded as a positive reinforcement for the

Table 8 . Results of the analyses of variance for five courseware packages: $F$-values of significant main effects $(\alpha \leqslant 0.05)$

\begin{tabular}{|c|c|c|c|c|c|}
\hline \multirow{2}{*}{$\begin{array}{l}\text { Background } \\
\text { variable }\end{array}$} & \multicolumn{5}{|c|}{ Courseware package } \\
\hline & A & B & $\mathrm{C}$ & $\mathrm{D}$ & $\mathbf{E}$ \\
\hline Gender & - & 9.79 & - & 4.78 & 4,42 \\
\hline Grade & - & 4.71 & - & 4.09 & - \\
\hline \multicolumn{6}{|l|}{ Computer experience outside } \\
\hline school hours & 3.84 & - & - & - & - \\
\hline Age & - & - & 7.75 & 一 & - \\
\hline Technology-enriched school & * & * & 3.97 & - & $*$ \\
\hline
\end{tabular}


technology-enriched schools to continue with the use of computers in education. It motivates the students positively. The teachers should pay attention to the nature of the courseware and how they use it in the lessons. The lesson in the computer room should not be a repetition of the previous lesson in an ordinary classroom.

\section{REFERENCES}

1. Moonen J. C. M. M. and Beishuizen J. J., Technology-enriched schools in the Netherlands. In Technology-Enriched Schools. Nine Case Studies with Reflections (Edited by Collis B. and Carleer G.), pp. 67-77. ISTE, Eugene, Ore. (1992).

2. Doornekamp B. G. and Carleer G. J., Computers integrated in the curriculum: can it be realized? In The Ninth International Conference on Technology and Education, 1992: Education "Sans Frontières", Vol. 3 (Edited by Estes N. and Thomas M.), pp. 1556-1558. College of Education, Univ. of Texas at Austin, Austin, Tx (1992).

3. van Diggele J. B. H. and Carleer G. J., Computergebruik en courseware-selectie door docenten van de proefscholen. Voortgangsverslag COMPRO-project; serie "PRONTO-rapporten" No. 7. Universiteit Twente-OCTO, Enschede (1990).

4. Doornekamp B. G. and Carleer G. J., The integration of computers in the classroom. In What is the Future of Computers in Education? (Edited by Moonen J. C. M. M. and Beishuizen J. J.). In preparation (1993).

5. Doornekamp B. G., The valuation by students of the use of computers in education. Paper presented at the ECER 1992, 22-25 June 1992. Enschede, The Netherlands. University of Twente - OCTO, Enschede (1992).

6. Kinzie M. B. and Sullivan H. J., Continuing motivation, learner control, and CAI. Educl Technol. Res. Dev. 37, 5-14 (1989).

7. Krendl K. A. and Lieberman D. A., Computers and learning: a review of recent research. J. Educl Computing Res. 4, 367-389 (1988).

8. Perez E. C. and White M. A., Student evaluation of motivational and learning attributes of microcomputer software. J. Computer-Based Instr. 12, 39-43 (1985).

9. Marcoulides G. A., An examination of cross-cultural differences toward computers. Computers Human Behav. 7 , 281-289 (1991).

10. Ransley W., An instrument for measuring five aspects of children's attitudes towards microcomputers. Br. J. Educ. Technol. 22, 216-221 (1991).

11. Chen M., Gender Differences in Adolescent's Uses of and Attitudes Towards Computers. Stanford Univ., Ann Arbor (1986).

12. Aşkar P., Yavuz H. and Köksal M., Students' perceptions of computer assisted instruction environment and their attitudes towards computer assisted learning. Educl Res. 34, 133-139 (1992).

13. Seymour S. L., Sullivan H. J., Story N. O. and Mosley M. L., Microcomputers and continuing motivation. Educl Commun. Technol. J. 35, 18-23 (1987).

14. Spaulding C. L., Motivation in the Classroom. McGraw-Hill, New York (1992).

15. Bond Jr N. A., Motivating the Student in CAI Technical Courses. Univ. of Southern California, Los Angeles (1971).

16. Kinzie M. B., Requirements and benefits of effective interactive instruction: learner control, self-regulation, and continuing motivation. Educl Technol. Res. Dev. 38, 5-21 (1990).

17. Doornekamp B. G. and Carleer G. J., Integratie van computers en courseware in het onderwijs na vier jaar. Voortgangsrapport schooljaar 1991/1992; serie "PRONTO-rapporten" No. 21. Universiteit Twente-OCTO, Enschede (1993).

18. Doornekamp B. G., The valuation by students of the use of computers in education. In European Conference on Educational Research. Book of Summaries: Vol. 2 (Edited by Plomp Tj., Pieteres J. M. and Feteris A.), pp. 605-608. Univ. of Twente, Enschede (1992).

19. Doornekamp B. G., Vergelijking tussen de papier \& pen versie en de computerversie van de 'Motivatie'-vragenlijst. Paper presented at the ORD 1993, 25-27 May, Maastricht, The Netherlands. Universiteit Twente-OCTO, Enschede (1993).

20. Lindvall C. M. and Nitko A. J., Measuring Pupil Achievement and Aptitude, 2nd edn. Harcourt Brace Jovanovich, New York (1975).

21. Hayman Jr J. L., Research in Education. Merrill, Columbus, Ohio (1968).

22. Oudejans L., Prinsen Geerligs M., Van de Put J. and Rietveld M., Een vergelijking tussen de schriftelijke afname en een geautomatiseerde afname van de SchoolVragenLijst. Psychol. Computers 9, 51-56 (1992).

23. Educational Centre (OC), Twente Advanced Interactive Graphic Authoring System. University of Twente, Enschede (1987). 